\title{
Assessing nursery contribution to recruitment: relevance of closed areas to haddock Melanogrammus aeglefinus
}

\author{
P. J. Wright*, D. Tobin, F. M. Gibb, I. M. Gibb \\ Marine Scotland, Marine Laboratory, 375 Victoria Road, Aberdeen AB11 9DB, UK
}

\begin{abstract}
Closing areas where juveniles aggregate has often been assumed to benefit recruitment since it reduces mortality of undersized individuals. However, the number of juveniles per unit area that recruit to an adult population may vary due to a combination of factors. Consequently, more appropriate nursery definitions have been based on measures of juvenile contribution to an adult population, either as overall contribution (essential juvenile habitat hypothesis) or recruits per area (the nursery role hypothesis). Nonetheless, these definitions do not explain why nursery contribution differs. In the present study, the nursery contribution of areas in the North Sea and west of Scotland was examined for haddock Melanogrammus aeglefinus. Elemental concentrations in the equivalent parts of the otolith of juvenile and adult fish were compared from the same year-class. Discriminant analysis indicated that 4 discrete 0 -group regions around the Scottish coast could be distinguished with a classification accuracy of 83 to $89 \%$. In contrast, the elemental signatures from adult cores sampled in adjacent spawning areas indicated high levels of mixing throughout the study region. The Scottish east coast region accounted for the highest overall contribution in 2003, and this was related to the high 0 -group density in that region. While 0 -group densities in this area have been consistently high since 2001, previous large year-classes have been characterised by high densities further north and east. Therefore, if 0 -group density is always a good indicator of nursery contribution, temporary area closures that vary in relation to juvenile settlement concentrations may have more benefit to recruitment than permanent closures.
\end{abstract}

KEY WORDS: Nursery value $\cdot$ Haddock $\cdot$ Connectivity $\cdot$ Otolith microchemistry $\cdot$ North Sea $\cdot$ West of Scotland Resale or republication not permitted without written consent of the publisher

\section{INTRODUCTION}

The utility of closed areas in conserving fish stocks has not been widely accepted due to the concern that any benefits of overspill and export of young to unprotected areas may not compensate for the impact of re-distributed fishing effort (Halpern et al. 2004). Nevertheless, evidence from modelling suggests that protecting areas where juveniles congregate can have a significant positive benefit by reducing undersized mortality (Horwood et al. 1998, Le Quesne et al. 2007). Protecting the densest aggregations of juveniles may have a conservation benefit if the criteria used to assess the location of nursery areas reflect the relative contribution of juveniles to the adult population. This could be possible since regular research surveys pro- vide an annual estimate of 0-group density distribution for many fish stocks. However, density is only one of a combination of factors that influence the numbers of juveniles that recruit to the adult population. For example, while some sites may be well placed to receive larval influx, they could be areas where juveniles grow slowly, mortality is higher, or movement to adult habitat is risky or difficult (Lipcius et al. 1997, McBride \& Able 1998). For this reason, Beck et al. (2001) proposed that a habitat should be defined as a nursery for juveniles if the contribution per unit area of recruits to the adult population was greater, on average, than other habitats in which juveniles occur. Dahlgren et al. (2006) highlighted that contribution by area may ignore important sources of juveniles, and so defined nursery value based on the overall contribu- 
tion of juveniles to adult populations. While the focus on contribution in both measures is essential in defining a nursery area, neither formulation considers the relative significance of possible determining factors, i.e. density, growth, survival and subsequent movements. Hence, further information is needed in order to clarify why a nursery area or habitat makes a substantive contribution to an adult population.

Assessing connectivity between nursery and spawning areas has become possible through the use of otolith microchemistry. Elemental concentrations in the equivalent parts of the otolith of juvenile and adult fish from the same year-class can provide a natural tag allowing movements to be inferred (Gillanders \& Kingsford 1996, Thorrold et al. 2001, Gillanders 2002, Wright et al. 2006a). Regional variation in water chemistry and temperature can result in differences in incorporation of certain elements, such as barium (Ba) and strontium (Sr), into the otolith (Bath et al. 2000, Walther \& Thorrold 2006, Dorval et al. 2007). The reasons for differences in concentrations of other otolith elements are not as well understood, although a range of factors, including diet and physiological constraints on endolymph chemistry, may play a role (Campana 1999, Miller et al. 2006).

A number of otolith microchemistry studies have demonstrated differences in the nursery contribution among estuarine and inshore habitats. For example, Gillanders \& Kingsford (1996) found that the highest proportion of blue groper Achoerodus viridis, which recruit to rocky reefs, had a juvenile otolith composition indicative of an estuarine seagrass habitat. Similar studies on species of flatfish (Yamashita et al. 2000, Brown 2006) and white perch Morone americana (Kraus \& Secor 2005) have also suggested that the estuarine contribution of juveniles to the adult populations was much higher than would be expected based on the relative area of nursery habitats. While these studies highlight the importance of specific habitats as nurseries, none of them considered whether differences in the contribution of nursery habitats were related to juvenile density.

Assessing nursery contribution in large commercial fish stocks inhabiting the open sea may be challenging because of the much broader spatial scale over which water chemistry varies. Comparatively small differences in otolith chemistry have been recorded between groups that are $>100 \mathrm{~km}$ apart in the open sea, while large differences have been found between estuarine and coastal groups $<10 \mathrm{~km}$ apart (Gillanders et al. 2001, Elsdon et al. 2008). Juvenile aggregations can also be very extensive $(>10 \mathrm{~km})$ in the open sea (e.g. Fernandes \& Rivoirard 1999). As such, while studies of inshore areas may consider nursery contribution in relation to discrete benthic habitats, studies of off- shore areas need to be conducted at a much larger scale that captures the association with chemically different water masses.

Concern over high mortality in juvenile haddock Melanogrammus aeglefinus has led to area restrictions on the small mesh fishery for Norway pout in the North Sea (Anon. 1987) and the permanent closure of the Emerald and Western Banks in the northwest Atlantic (Frank et al. 2000) and an area of Rockall Bank (Newton et al. 2008). However, no clear effect of these restrictions on juvenile mortality has been demonstrated. Closing areas may also have a negative impact on juvenile haddock in cases where their predators are protected (Jaworski et al. 2006, Temming et al. 2007). Therefore, it is important to have a better understanding of nursery contribution to determine whether site protection is a useful management strategy for this and related species. As the contribution from nursery areas can change over time (Kraus \& Secor 2005) it is also important to understand the causes of varying contribution.

In the North Sea, haddock generally occur north of the Dogger Bank with major spawning areas in the northeast of the North Sea and close to the Scottish east coast (Saville 1959). There appears to be little exchange between the eastern and western North Sea based on both tag-recapture evidence (Jones 1959, P. J. Wright \& D. Tobin unpubl. data) and differences in transferrin allozyme frequency (Jamieson \& Birley 1989). Haddock spawn from late February through to mid-April (Saville 1959, Wright \& Gibb 2005) and the larvae metamorphose to pelagic juveniles at around 20 to $30 \mathrm{~mm}$ in length and 2 to 3 mo from hatching (Bailey 1975). Although the largest spawning biomass occurs in the North Sea, hydrodynamic model simulation of the transport of the pelagic phases suggests that significant quantities of haddock in this region could originate from off the Scottish west coast (Heath \& Gallego 1997). Juveniles settle from June to August at a total length (TL) of 40 to $80 \mathrm{~mm}$ (Bailey 1975, Bromley \& Kell 1999). They feed benthically over a wide range of sediments including clay, sand and gravel (Bigelow \& Schroeder 1953, Lough et al. 1989) and aggregations in the North Sea can be in the order of $100 \mathrm{~km}$ across (Fernandes \& Rivoirard 1999).

In the present study, the contribution of 0-group fish from the 2003 year-class to age 3 adult haddock in the northwest North Sea and ICES area VIa (west coast of Scotland) was assessed using measures of both nursery value (Beck et al. 2001) and essential juvenile habitat (Dahlgren et al. 2006). Additionally, an adaptation of Beck et al.'s (2001) formula was applied in which the proportional contribution of each juvenile area was expressed as a function of juvenile density in that area. Unlike the contribution per unit area metric used by 
Beck et al. (2001), this new method does not assume that juveniles are evenly dispersed among all habitat areas and so accounts for differences in 0-group density in the estimation of contribution. Otolith elemental composition of 0-group juveniles and the corresponding portion of the otolith of age 3 adults were determined using solution-based inductively coupled plasma mass spectrometry (ICP-MS). Together with survey data, regional differences in juvenile otolith microchemistry were used to define nursery regions in the North Sea and west of Scotland. From this analysis, an assessment was made of the scale of connectivity between life stages, and the efficacy of closing areas as a fisheries management tool was evaluated.

\section{MATERIALS AND METHODS}

Juvenile distributions. Data on 0-group distribution were obtained for the period 1996 to 2004 from 2 annual pre-recruit surveys, the ICES International Bottom Trawl 3rd quarter surveys of the North Sea and the Scottish 4 th quarter survey of ICES region VIa. These surveys use the Grande Ouverture Verticale (GOV), a high-headline bottom trawl fitted with a $20 \mathrm{~mm}$ cod end liner. Data on numbers of age 0 haddock in the North Sea were obtained directly from ICES (DATRAS). Numbers at length were converted to numbers at age 0 in the Scottish 4 th quarter survey using area- and year-specific age-length keys. All catches were standardised to numbers per hour tow. As data were collected over a period of several weeks, numbers were corrected to represent density on a single survey date. The ICES estimate of natural mortality $(M)$ for 0-group haddock (2.05) was used to reduce numbers according to:

$$
N_{\mathrm{e}}=\exp \left[\ln N_{\mathrm{c}}+\left(M \cdot \frac{t}{365}\right)\right]
$$

where $N_{\mathrm{e}}$ is the estimated number of 0-group on the 31 August, $N_{\mathrm{C}}=$ the number of 0 -group caught and $t$ is the number of days from 31 August.

In order to consider regional changes in abundance, 4 regions were defined covering the major areas of haddock distribution: northwest (NW), Northern Isles (NI), the Scottish east coast (SEC) and offshore North Sea (ONS) (see Figs. 1 \& 2). Numbers of 0-group haddock per $\mathrm{km}^{2}\left(N_{\mathrm{r}}\right)$ were estimated as:

$$
N_{\mathrm{r}}=N_{\mathrm{e}} \cdot \frac{A_{\mathrm{r}}}{A_{\mathrm{s}}}
$$

where $N_{\mathrm{e}}$ is taken from Eq. (1); $A_{\mathrm{r}}$ is the total sea surface area $\left(\mathrm{km}^{2}\right)$ of seabed $<250 \mathrm{~m}$ depth within each ICES rectangle (estimated from a bathymetric map of resolution 1:250000 [British Geological Survey] im- plemented within ArcGIS [ESRI]); and $A_{\mathrm{s}}$ is the area swept $\left(\mathrm{km}^{2}\right)$ based on a predetermined 'effective gear width' (wing spread for the GOV trawl was estimated to be $22 \mathrm{~m}$; Reid et al. 2000) and distance of the survey tows.

Swept area abundance of 0-group haddock for the 4 regions were expressed as a proportion of the total abundance for the study area, in order to consider temporal changes in the importance of regions. The relationship between regional swept area abundance and North Sea 0-group abundance from assessed numbers at 1 July (ICES 2008a) was considered using Pearson and Spearman rank correlation.

Juvenile sample collection. Samples of $>60$ juvenile 0-group haddock ranging from 95 to $182 \mathrm{~mm}$ (mean $134 \mathrm{~mm}$ ) TL were collected by bottom trawl from August to October 2003 onboard FRV 'Clupea' at 5 locations in 3 of the 4 regions defined for juvenile aggregations (see Fig. 1); SEC (2 locations: Buchan coast and Moray Firth), NI (near Orkney) and NW (2 locations: north Minch and south Minch). Based on length at age relationships for 0-group haddock (Wright \& Gibb 2005) and assuming a settlement size of $50 \mathrm{~mm}$, these fish would be expected to have been settled on the grounds for at least $40 \mathrm{~d}$ with an average period from settlement to capture of $80 \mathrm{~d}$. Adult haddock were sampled onboard FRV 'Scotia' in 2006 during the spawning period, at 4 locations close to juvenile sample locations and the major adult aggregations (see Fig. 2). For each fish, information on total fish length $( \pm 1 \mathrm{~mm})$, total and eviscerated wet weight $( \pm 0.1 \mathrm{~g})$ were collected. Sagittae were removed with enameltipped forceps and preserved dry in acid-washed plastic vials. Estimates of annual age from the sagittal otoliths were used to identify the 2003 year-class at age 0 and age 3 .

Otolith elemental analysis. In preparation for elemental analysis, sagittal otoliths were placed in acidwashed vials filled with $18 \mathrm{M} \Omega$ doubly deionised water. Any adhering tissue was removed using acidwashed ceramic-tipped forceps and a series of sonification steps. Otoliths of the 0-group juveniles were analysed whole. They were weighed to the nearest $1 \mu \mathrm{g}$ and stored in their vials prior to transportation to the Research and Productivity Council (RPC) in New Brunswick, Canada for elemental analysis. Adult sagittae were mounted in Araldite resin (Araldite CY212, Agar Scientific) and sectioned through the core using a low-speed sectioning saw (Buehler). The exposed surfaces were wiped with dilute nitric acid to remove any adhering resin dust. Samples from the core region were extracted from the sectioned otoliths using a computerised numerical-control milling machine, (Micromill $^{\mathrm{TM}}$, New Wave Research) following the procedure of Charlier et al. (2006). A threshold core 
length, width and depth limit was set by averaging the cross-sectional area of otoliths from a select group ( $n=4$ ) of 0-group juveniles representing the lower size range ( $\leq 100 \mathrm{~mm}$ TL haddock). Prior to sample drilling, a milling area was predefined electronically to ensure that only material from the 0-group part of the otolith core was included. The core was drilled to an approximate depth of $400 \mu \mathrm{m}$ (by two $200 \mu \mathrm{m}$ passes) and was performed through a drop of $18 \mathrm{M} \Omega$ doubly deionised water to prevent dispersal of fine sample dust released by the milling action. The sample was then collected by transferring the liquid overlay into a pre-nitric acidwashed sample tube and then left to dry within a laminar flow fumehood. All adult core samples were then sent to the ICP-MS facility at RPC. Due to inherent difficulties in weighing the fine powder accurately, all element data were normalised as a ratio of calcium, and concentrations were derived as a function of pure $\mathrm{CaCO}_{3}$.

All otoliths were randomly ordered to prevent sample batch bias. Due to the differences in sample size and weight, the preparation of juvenile and adult core material was designed to account for these differences. Juvenile whole otolith samples were immersed in $1 \mathrm{ml}$ $50 \%$ ultra high purity (Seastar) $\mathrm{HNO}_{3}$ for $30 \mathrm{~min}$ at room temperature. The mix was then held at $80^{\circ} \mathrm{C}$ for $15 \mathrm{~min}$ to complete the reaction. Adult core samples were also immersed in acid of comparable acid:material ratio to that of the whole juvenile otoliths $(0.13 \mathrm{ml}$ $50 \%$ ultra high purity [Seastar] $\mathrm{HNO}_{3}$ ) for $30 \mathrm{~min}$ at room temperature. The mix was then held at $70^{\circ} \mathrm{C}$ for 30 min to complete dissolution of the sample. To quantify potential contamination during the cleaning and preparation process, a series of blank acid-washed vials and samples of resin were prepared in the same manner. The elemental signature of all samples was analysed using a Thermo X-7 ICP-MS (equipped with a Thermo HPI interface). The instrument was operated using an autosampler to increase processing and instrument loading speed and thereby reduce instrument drift. In a measurement run, a series of blanks and matrix-matched standards were analysed throughout to allow for dynamic drift correction. Indium $\left({ }^{115} \mathrm{In}\right)$ was added to each sample as an internal standard. Quantification of strontium (Sr) and barium (Ba) was based upon isotope dilution analysis. Each sample was spiked with an enriched isotope cocktail containing known concentrations of target isotopes, closely tailored to the average of the concentrations expected in the samples. Therefore, there was no reliance on external reference materials or standards for the elements listed. A series of precisely known commercial calibration standards (NIST traceable single element calibration solutions; SCP Science) were used to consider accuracy for other elements. Analytical precision within and between runs was verified by the analysis of an otolith 'pool' sample (a composite of all the prepared otolith solutions) which was run a total of 52 times at regular intervals throughout the sample runs. The variability of the 'pool' results was considered the best indication of the expected variability of the sample data. The standard deviation (SD) (as a percentage of the mean value) of this reference pool (>18 measurements in each run) was used as a measure of precision. Ba deviated by $<2.5 \%$ between measurements, manganese $(\mathrm{Mn})<2.0 \%$ and $\mathrm{Sr}<1.4 \%$. Separate laboratory reagent blanks were prepared and analysed concurrently with the samples. Variability of the results for the blanks was considered the best indication of sensitivity to detection for each element. Based on the method of Jónsdóttir et al. (2007), a measure of the detection limits for each element was calculated as 3 times the SD of the blank: Ba, $0.03 \mu \mathrm{g} \mathrm{g}^{-1} ; \mathrm{Mn}, 0.3 \mu \mathrm{g}$ $\mathrm{g}^{-1}$; and $\mathrm{Sr}, 0.01 \mathrm{mg} \mathrm{g}^{-1}$.

Statistical analysis of elemental data. A total of 33 isotopes representing 23 elements were measured using ICP-MS. All element concentrations were tested for the assumption of normality (following natural logtransformation where appropriate) and homogeneity of variance using the Kolmogorov-Smirnov test and the Hartley F-max test, respectively. Data fulfilling normality and homogeneity of variance assumptions were obtained for 3 elements for both juvenile and adult cored material $\left({ }^{86} \mathrm{Sr}\right.$ and log-transformed ${ }^{137} \mathrm{Ba}$ and ${ }^{55} \mathrm{Mn}$ ). Analysis of covariance (ANCOVA) was used to assess whether fish length or otolith weight had an effect on the magnitude of each variable.

To determine whether there were significant differences among sites for individual elements and multi-element concentrations, ANOVA and multivariate analysis of variance (MANOVA) were used where location was considered as a random factor. Bonferroni pair-wise comparison tests were used to identify significant differences among the sample locations. Discriminant analysis (DA) was used to separate groups by applying a dimension reduction to the data (Huberty 1994). A jackknife procedure was used to estimate classification success. Due to uneven sample sizes, DA was conducted using uniform rather than proportional priors to reduce potential classification bias (see White \& Ruttenberg 2007). The assignment of elemental compositions of adult individuals to juvenile nursery areas used Millar's constrained maximum likelihood estimator (Millar 1990a). Results for this estimator were obtained from a multipurpose simulation-bootstrap analysis program, HISEA (Millar 1990b). The program assumes that the variables used are approximately distributed as multivariate normal and that they have a covariance matrix that is common to all samples. Variability in classification was estimated by bootstrapping 
( $\mathrm{n}=1000$ ) the data (see Millar 1990a,b). The absolute error was estimated as the difference between the known contribution of juveniles and the estimated mean contribution. As the baseline data may not be representative of the actual mixed population, additional simulations were conducted in which the baseline sample was randomly subsampled to simulate both equal and unequal samples sizes.

Nursery contribution. As only the 3 coastal regions were sampled for otolith chemistry, the estimation of contribution was confined to just these regions; SEC, NI and NW (see Fig. 2). As adult abundance by region could only be estimated following the survey, adult chemistry samples were randomly subsampled to reflect the proportions of age 3 haddock in each of the 3 regions as estimated from the survey, giving 38, 37 and 25 from NW, NI and SEC, respectively. Estimates of the proportion of all adults whose otolith cores were assigned to a particular juvenile region $\left(C_{j}\right)$ were then estimated using HISEA and used in the following indices of nursery definition. Dahlgren et al. (2006) proposed that only $C_{j}$ should be considered. The nursery value $(N H)$ of Beck et al. (2001) can be given as:

$$
N H_{j}=\frac{C_{j}}{A_{j}}
$$

where $A_{j}$ is the area of the contributing juvenile habitat or region. In the present study, $A_{j}$ was expressed as a proportion of the total sea area $<250 \mathrm{~m}$ for the 3 study regions. Values $>1$ indicate above average contribution of juveniles per unit area. The adapted measure of nursery contribution, 'nursery density value' (ND), included terms for both contribution and density based on the abundance of juveniles in each region as a proportion of the total abundance:

$$
N D_{j}=\frac{C_{j} \cdot A_{j} \cdot N_{A}}{N_{j}}
$$

where for juvenile region $j, N_{j}$ is the number of 0 -group in a region expressed as a proportion of the 3 regions and $N_{A}$ is the number of regions (3). Values of $N D_{j}$ close to 1 indicate that contribution was proportional to the 0 -group density over that region. Values greater or less than 1 are indicative of regional differences in mortality rate or movements.

\section{RESULTS}

\section{Distribution of juvenile and adult haddock}

At the ICES rectangle scale, the highest densities of 0-group haddock in 2003 occurred off the SEC (Buchan and Moray Firth), being an order of magnitude higher than in other juvenile regions (Fig. 1). The only other surveyed ICES rectangle of similar high

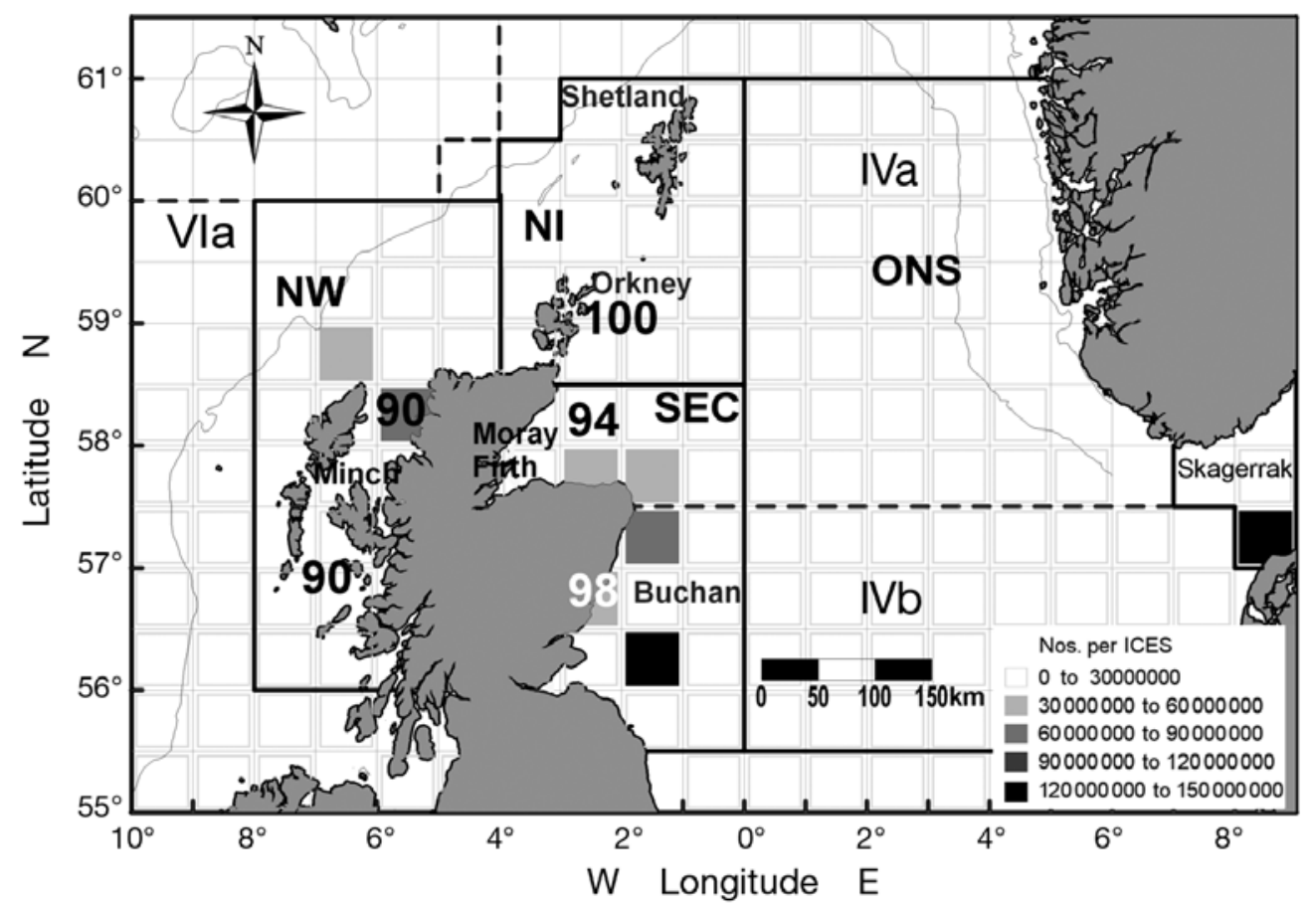

Fig. 1. Melanogrammus aeglefinus. Distribution of 0-group haddock in August (North Sea) and November (VIa) 2003 in ICES bottom trawl surveys. Shading refers to $\mathrm{n} \mathrm{km}^{-2}$ swept area (see Eq. 2). Location and size of 0-group samples is indicated by numbers. Four sample regions, Scottish east coast (SEC), Northern Isles (NI), northwest (NW) and offshore North Sea (ONS), are indicated by solid lines. Note NW sample region represents part of ICES stock VIa, while other sample regions (SEC, NI, ONS) are part of ICES stock regions IVa and/or IVb in the North Sea. ICES stock regions are indicated by dashed lines. Grey line indicates position of $200 \mathrm{~m}$ depth contour 
Table 1. Comparison of sea area $<200 \mathrm{~m}$ and proportional abundance by region for the 4 surveyed regions of the study area (see Fig. 1). NW: northwest, NI: Northern Isles, SEC: Scottish east coast, ONS: offshore North Sea

\begin{tabular}{|c|c|c|c|}
\hline \multirow[t]{2}{*}{ Region } & \multirow[t]{2}{*}{ Area $\left(\mathrm{km}^{2}\right)$} & \multicolumn{2}{|c|}{ Proportion by region } \\
\hline & & Age 0 & Age 3 \\
\hline NW & 76750 & 0.16 & 0.33 \\
\hline NI & 58426 & 0.01 & 0.32 \\
\hline SEC & 59176 & 0.4 & 0.21 \\
\hline ONS & 292960 & 0.43 & 0.14 \\
\hline
\end{tabular}

density occurred in the Skagerrak off the north Danish coast $\sim 500 \mathrm{~km}$ from juvenile and adult samples analysed in the present study. Estimates of 0-group haddock abundance in the 4 defined regions, expressed as a proportion of the total study area, are presented in Table 1. The abundance of 0 -group in the SEC region was similar to that in the much larger ONS region. The NI region accounted for the smallest proportion of 0 -group fish. In contrast, the same region accounted for almost one-third of the total abundance of age 3 haddock, with very high densities in the ICES rectangles east of Orkney (Fig. 2). High densities of haddock were also observed in some of the ICES rectangles in the SEC region. However, the proportion of age 3 adults in the NW region was greater due to the larger area of this region (Table 1). The ONS region only accounted for $14 \%$ of the total abundance of age 3 fish in 2006 (Table 1) and was not sampled for otolith analysis.

Temporal trends in the swept area abundance of 0group haddock by region, expressed as the proportion of the total study area, are given in Fig. 3. This shows that there was little temporal consistency in the proportional representation of individual areas to total 0 -group haddock abundance. Although there was no significant trend with year-class strength, the SEC region tended to account for a higher proportion of the total abundance in years of poor recruitment, i.e. 2002 to 2004. Conversely, high 0-group abundance in the ONS coincided with the very large 1999 year-class.

\section{Variability in otolith chemistry between nursery grounds}

No significant interactions were observed between elemental concentration and either TL or otolith weight (ANCOVA; $\mathrm{p}>0.05)$. Homogeneity of variance assumptions were met for $\mathrm{Mn}$ and $\mathrm{Sr}(\mathrm{p}>0.05)$ but were violated in $\mathrm{Ba}$ due to a single sample location (Moray Firth). Highly significant differences were

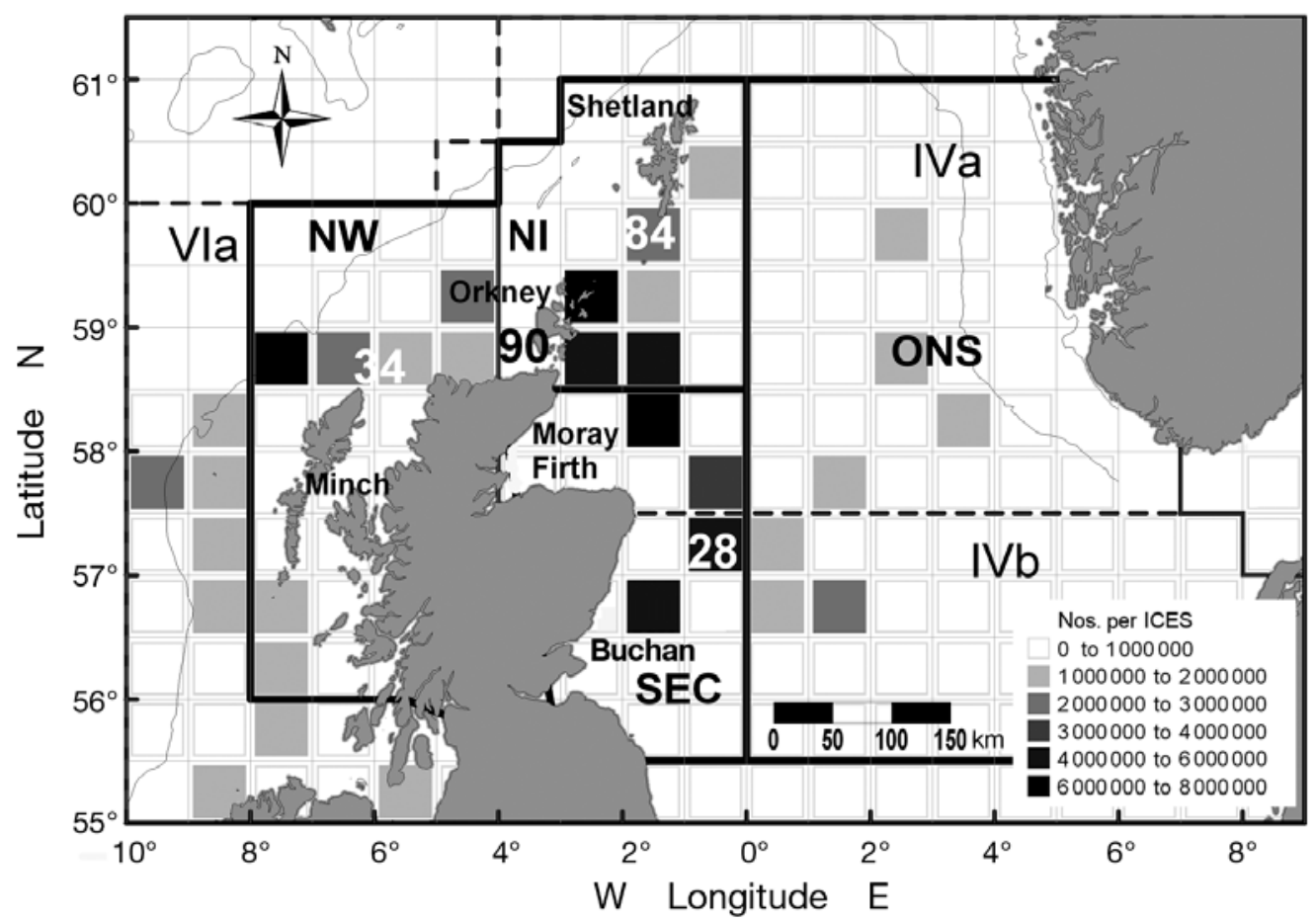

Fig. 2. Melanogrammus aeglefinus. Distribution of age 3 haddock in February (North Sea) and March (VIa) 2006 in ICES bottom trawl surveys. Shading refers to $\mathrm{n} \mathrm{km}^{-2}$ swept area (see Eq. 2). Location and size of age 3 samples is indicated by numbers. ICES stock regions VIa, IVa and IVb (northern and central North Sea) are indicated by dashed lines and 4 sample regions (SEC: Scottish east coast, NI: Northern Isles, NW: northwest, ONS: offshore North Sea) are indicated by solid lines 


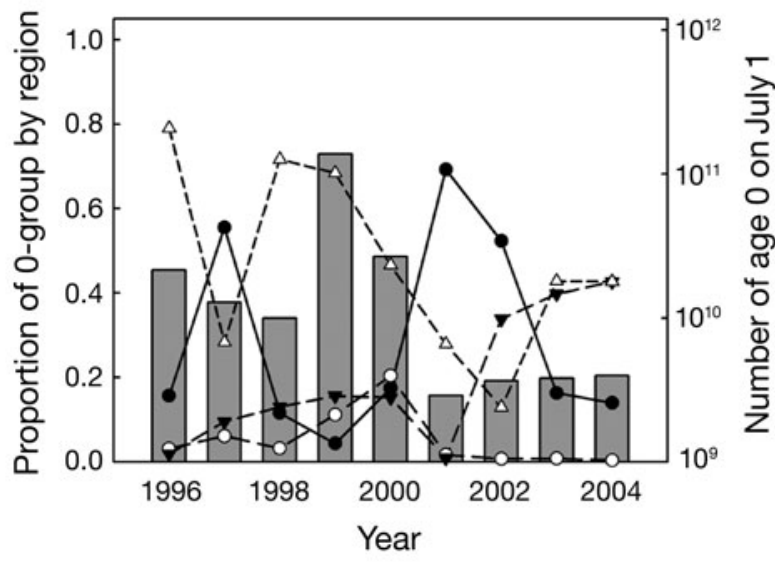

Fig. 3. Melanogrammus aeglefinus. Changes in abundance of 0-group haddock by region (see Fig. 1) between 1996 and 2004 expressed as a proportion of the total abundance in the study area. Numbers of 0-group on July 1 (grey bars and right axis) in the North Sea (region IV) based on an assessment (ICES 2008a) are given for comparison. (O) Northern Isles, (•) northwest, $(\Delta)$ offshore North Sea, $(\boldsymbol{\nabla})$ Scottish east coast

found in element concentrations among sample locations (Mn, Ba and Sr: ANOVA; $\mathrm{p}<0.001 ;$ Fig. 4). While concentrations of $\mathrm{Mn}$ and $\mathrm{Ba}$ differed among many locations, only otoliths from the Buchan area had significantly elevated Sr concentrations compared with elsewhere. Pairwise comparisons of otolith multi-element composition indicated that all but one combination of locations differed significantly (MANOVA; $\mathrm{p}<$ 0.001). Otoliths from the north and south Minch locations did not have different chemical compositions (MANOVA; $\mathrm{p}=0.168$ ). Consequently, data from these 2 locations were combined into a single 'Minch' sample for subsequent analysis. The remaining 4 juvenile sample locations could be distinguished with $>83 \%$ classification accuracy (Table 2).

Maximum likelihood-based simulations based on the 0 -group samples were used to test the effectiveness of

Table 2. Melanogrammus aeglefinus. Classification success of the quadratic discriminant function analysis for juvenile haddock from 4 nursery areas. Data presented are the percentage of otoliths from the region of origin (columns) classified to each of the 4 regions (rows). Total no. $(\mathrm{N})$ of fish examined and no. correctly assigned is also given

\begin{tabular}{|lrrrr|}
\hline Region & Buchan & Moray Firth & Orkney & Minch \\
\hline Buchan & 81 & 2 & 7 & 17 \\
Moray Firth & 0 & 53 & 1 & 9 \\
Orkney & 5 & 0 & 88 & 4 \\
Minch & 5 & 6 & 3 & 150 \\
Total N & 91 & 61 & 99 & 180 \\
N correct & 81 & 53 & 88 & 150 \\
Proportion & 0.89 & 0.87 & 0.89 & 0.83 \\
\hline
\end{tabular}

the elemental concentration data in providing a robust estimate of contribution. The actual contribution from these samples ranged in proportion from 0.14 to 0.42 depending on location (Table 3 ), while the estimates of contribution ranged in proportion from 0.12 to 0.43 . These estimates were in general agreement with the known proportions giving a summed error rate of 0.06 for all combinations. Estimates of contribution from 2 additional hypothetical data sets based on resampled proportions of the real data were similarly robust, with the highest sum difference being 0.10 . This indicated that the maximum likelihood approach could accurately estimate contribution using the data available.

The discriminant scores of adult cores appeared to fit well in the discriminant space defined by the juvenile groups, suggesting that the baseline sampling of juvenile groups contained all the reference groups of impor-

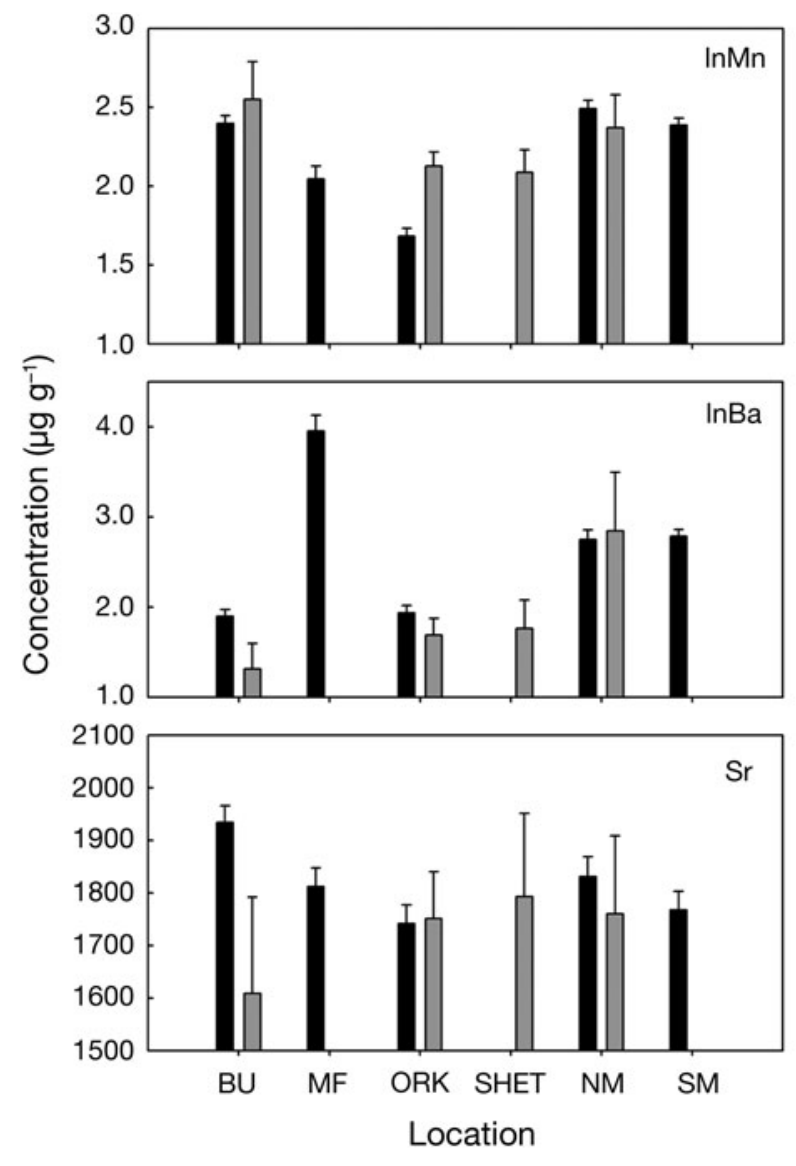

Fig. 4. Melanogrammus aeglefinus. Mean concentrations of otolith elements used for 0-group juvenile (black bars) and adult (grey bars) core haddock samples from sampled locations (see Fig. 1). Orkney and Shetland adult samples both belong to the Northern Isles $(\mathrm{NI})$ region. $\mathrm{BU}=$ Buchan, $\mathrm{MF}=$ Moray Firth, ORK = Orkney, SHET $=$ Shetland, NM = north Minch, SM = south Minch. Note that the concentrations of Mn and $\mathrm{Ba}$ are expressed as the natural logarithm. Error bars represent $95 \%$ CI 
Table 3. Melanogrammus aeglefinus. Actual and hypothetical proportions of juveniles from each area are presented along with estimates of these proportions based on Millar's constrained maximum likelihood analysis of a mixed juvenile sample. Data for actual contribution and 2 hypothetical simulations with equal (simulation 1) or unbalanced (simulation 2) proportions of juveniles from each area are presented. The error of all assignments (difference between known and estimated) was summed from the 4 nursery areas to provide a measure of model accuracy

\begin{tabular}{|lcccccc|}
\hline Nursery area (N) & Actual & Estimated & Simulation 1 & Estimated 1 & Simulation 2 & Estimated 2 \\
\hline Buchan (93) & 0.21 & 0.23 & 0.25 & 0.28 & 0.66 & 0.71 \\
Moray Firth (61) & 0.14 & 0.12 & 0.25 & 0.22 & 0.12 & 0.11 \\
Orkney (99) & 0.23 & 0.22 & 0.25 & 0.25 & 0.12 & 0.11 \\
Minch (185) & 0.42 & 0.43 & 0.25 & 0.25 & 0.10 & 0.07 \\
Sum error & & 0.06 & & 0.06 & & 0.10 \\
\hline
\end{tabular}

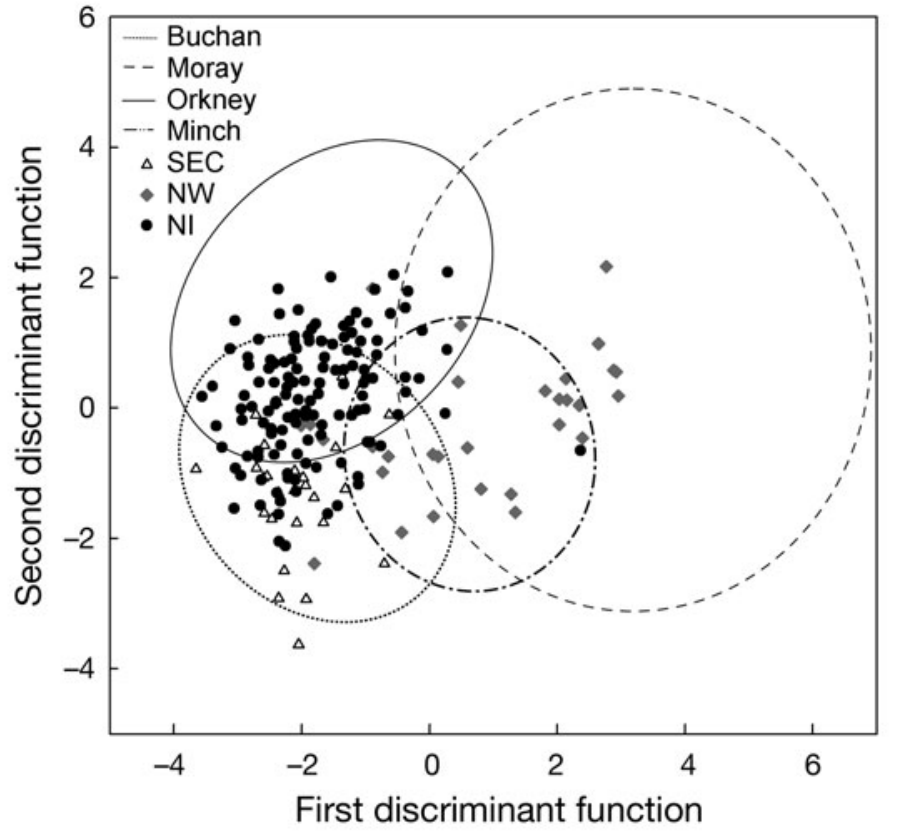

Fig. 5. Discriminant scores based on otolith chemistry using juvenile otoliths (95\% confidence ellipses) as reference groups. Discriminant scores of age 3 haddock Melanogrammus aeglefinus from spawning grounds were calculated from the juvenile group discriminant functions: $\mathrm{DF} 1=-1.856+2.165 \ln B a+$ $0.351 \operatorname{lnMn}-0.0025 \mathrm{Sr} ; \mathrm{DF} 2=5.45+0.29 \operatorname{lnBa}-3.13 \operatorname{lnMn}+$ 0.0005Sr. SEC: Scottish east coast, NI: Northern Isles, NW: northwest

tance for the adult assignment (Fig. 5). Based on the maximum likelihood analysis, a high percentage of the otolith core element concentrations of adults were not assigned to adjacent juvenile areas (Table 4). Adults sampled off the SEC were almost exclusively assigned $(97 \%)$ to the nearby Buchan juvenile area. Equally, NI adults from both Shetland and Orkney were largely (55\%) assigned to local juvenile areas but with a high percentage assignment from Buchan (42\%). The NW adults mostly (64\%) appeared to originate locally; however, there was also a substantial assignment to the Moray Firth (21\%) and Buchan (11\%) baseline. The
Table 4. Melanogrammus aeglefinus. Millar's constrained maximum likelihood estimates (and standard deviation [SD]) of relative contribution of baseline juvenile haddock to the adult spawning stock. Adult spawning groups are listed per column and juvenile baseline samples are listed per row. Northern Isles (NI) includes 2 adult samples from Orkney and Shetland, while other areas (SEC: Scottish east coast, NW: northwest) are represented by a single sample

\begin{tabular}{|c|c|c|c|}
\hline & SEC & NI & NW \\
\hline Buchan & $0.97(0.08)$ & $0.42(0.09)$ & $0.11(0.09)$ \\
\hline Moray Firth & $0.00(0.00)$ & $0.00(0.00)$ & $0.21(0.09)$ \\
\hline Orkney & $0.00(0.00)$ & $0.55(0.09)$ & $0.04(0.04)$ \\
\hline Minch & $0.03(0.08)$ & $0.03(0.03)$ & $0.64(0.12)$ \\
\hline
\end{tabular}

proportion contribution to non-local sources far exceeded the potential error in assignment from simulations, indicating that the assignments reflect juvenile movement among the defined regions.

\section{Nursery value}

For the purposes of estimating nursery contribution, adult assignment from Buchan and the Moray Firth were combined since they are both part of the SEC region. The importance of this SEC region as a net contributor to the adult population was evident from both the $\mathrm{C}_{j}$ and $\mathrm{NH}$ indices (Table 5). The similarity in the magnitude of differences among regions for $\mathrm{NH}$ and $\mathrm{C}_{j}$ were due to the small differences in sea area between these regions. In contrast, the juvenile density-corrected estimates of contribution, $N D$, indicated that contributions from the SEC and NW regions were largely proportionate to juvenile density, i.e. had values close to 1 . However, a very high $N D$ value was obtained for the NI because $10 \%$ of all adults appeared to originate from this region despite 0-group abundance being particularly low. Uncertainty in the estimation of contribution, based on the SD, did not alter the relative differences in $N D$ among regions. 
Table 5. Melanogrammus aeglefinus. Area, proportional abundance of haddock by juvenile and adult region and nursery contribution according to the methods of Dahlgren et al. (2006) $\left(C_{\mathrm{j}}\right)$, Beck et al. (2001) $(N H)$ and the present study $(N D)$. Values in parentheses refer to standard deviation (SD) for $C_{\mathrm{j}}$ and variation in computed values of $N H$ and $N D$ values based on these SDs. NW: northwest, NI: Northern Isles, SEC: Scottish east coast

\begin{tabular}{|c|c|c|c|c|c|c|c|c|c|}
\hline \multirow{2}{*}{ Region } & \multirow{2}{*}{$\begin{array}{l}\text { Area } \\
\left(\mathrm{km}^{2}\right)\end{array}$} & \multirow{2}{*}{$\begin{array}{l}\text { 0-group } \\
\text { (n) }\end{array}$} & \multirow{2}{*}{$\begin{array}{l}\text { Density } \\
\left(\mathrm{n} \mathrm{km}^{-2}\right)\end{array}$} & \multirow{2}{*}{$\begin{array}{l}\text { Proportion } \\
\text { area }\end{array}$} & \multicolumn{2}{|c|}{ Proportion abundance } & \multicolumn{3}{|c|}{ Nursery contribution- } \\
\hline & & & & & Age 0 & Age 3 & $C_{\mathrm{j}}$ & $\mathrm{NH}$ & $N D$ \\
\hline NW & 76750 & $2.07 \times 10^{8}$ & 2705 & 0.40 & 0.29 & 0.38 & $0.34(0.08)$ & $0.85(0.20)$ & $1.41(0.33)$ \\
\hline NI & 58426 & $9.95 \times 10^{6}$ & 170 & 0.30 & 0.01 & 0.37 & $0.10(0.06)$ & $0.33(0.20)$ & $9.00(5.40)$ \\
\hline SEC & 59176 & $5.06 \times 10^{8}$ & 8558 & 0.30 & 0.70 & 0.25 & $0.56(0.11)$ & $1.87(0.37)$ & $0.72(0.14)$ \\
\hline
\end{tabular}

\section{DISCUSSION}

The use of otolith chemistry to study nursery contribution requires significant elemental differences between regions and the identification of all contributing groups to the fish of unknown origin (Campana et al. 2000, Gillanders 2002). In the case of whole-solution ICP-MS, distinguishable groups of fish imply that there has been segregation among different locations during at least some stage of the life history. Furthermore, enough otolith material has to be incorporated during the time period when groups were segregated for these differences to be detected (Elsdon et al. 2008). There were significant regional differences in $\mathrm{Mn}, \mathrm{Ba}$ and Sr concentrations between demersal juvenile haddock aggregations. Indeed, elemental concentrations largely reflected those of co-occurring Atlantic cod Gadus morhua (Wright et al. 2006a, Gibb et al. 2007) and whiting Merlangius merlangus (Tobin et al. in press), with Shetland having the lowest concentration of Mn and the Moray Firth having the highest Ba concentration. The spatial scale of differences in the concentration of elements in the present study was also consistent with findings for a finer-scale sampling programme for juvenile cod (Wright et al. 2006a). While the otolith chemical composition of settled juvenile haddock will reflect the range of physico-chemical conditions experienced during planktonic, pelagic and demersal juvenile stages, most otolith material will have formed during the demersal phase. This is because otolith weight varies as a power of fish length (Hunt 1992) and the juveniles sampled will have more than doubled in length following settlement. Haddock also appear to show site fidelity for many weeks following settlement, based on the size progression of 0 group haddock in repeated trawl surveys of the same study site between spring and autumn (Demain 2009). The high discriminatory success of juvenile baseline concentrations should therefore provide a reliable indicator of the 3 regions as well as the 2 sampled locations within the SEC region. While we cannot be certain that the baseline data were composed of all possible contributing juvenile areas, the discriminant scores of adult haddock otolith cores fitted well into the discriminant space defined by the juvenile samples, suggesting that all baselines were included. As evident from the juvenile survey data (Fig. 1), not all juvenile concentrations were sampled and so it is possible that a source of adults was missing from the present study. However, the considerable distance between the adult sample locations and the only other high-density site of juveniles found in the Skaggerak, together with the past evidence for limited exchange between the west and east North Sea (Jamieson \& Birley 1989), suggests the Skaggerak would have been an unlikely source. Further, the chemical signature of the Skaggerak is likely to be very different from the samples examined because this is a transition zone between the estuarine Baltic and North Seas (Dybern et al. 1994).

Whilst there are now many studies that have used otolith microchemistry to examine connectivity and the role of nurseries, the present work has been conducted at a spatial scale relevant to fisheries management in temperate regions rather than between habitat types. High densities of demersal 0-group gadoids, such as haddock, may suffer from reduced growth through intra-specific competition and can be the subject of intense predation pressure due to associated predator aggregations (Temming et al. 2007). Hence, there is no reason to assume that dense aggregations will account for most adult recruits. Nevertheless, the region with the highest densities of 0-group fish in 2003, the SEC region, did make the greatest overall contribution to age 3 haddock in 2006. This region also had the highest nursery value according to the nursery role equation (Beck et al. 2001), since seabed area was similar in the 3 juvenile regions considered. However, the assumption that juvenile density is uniform over all contributing areas, inherent within the nursery role equation (Beck et al. 2001; also see Kraus \& Secor 2005), does not hold for this species. The relatively small overall contribution of the NI was far more significant when the density of 0 -group from this region was considered. Given the small overall contribution and numbers of 0 -group, this may reflect sampling bias. However, assuming that sampling bias was not the 
cause of this result and since 0-group fish sampled from the NI only contributed to the nearby adult sample location, it would appear that survivorship in the region was comparatively higher than in the other regions. Such relatively small aggregations may be regarded as 'high-quality' areas worth protecting. Conversely, at the stock level, the dense aggregations found in the SEC region would appear to have higher value given that most adult haddock appear to originate from that region. Regardless of how nursery value is defined, accounting for regional differences in juvenile density in the present study provides a possible explanation for differences in contribution that is not evident from other measures of nursery contribution.

The mixed origin of most adult spawning samples indicates substantial juvenile dispersal following settlement. Adult haddock sampled in the NI, in a region representing a traditionally large spawning aggregation (Saville 1959, Heath et al. 1994, Hedger et al. 2004), were almost exclusively associated with nursery areas from inshore areas off the east coast of the Scottish mainland. While the Moray Firth nursery areas appear to contribute to the northern part of the Scottish west coast, there was no evidence of the converse. Based on this widespread dispersal it is clear that the scale of connectivity is relevant to stock rather than sub-stock-level dynamics. This contrasts with the smaller-scale connectivity of cod inhabiting the same inshore areas (Wright et al. 2006a), where spawning coastal cod from a similar geographical region tend to originate from nearby nursery areas and adults tend to show high fidelity to spawning areas (Neat et al. 2006, Wright et al. 2006a,b). This difference in the scale of connectivity between species subject to the same mixed fishery suggests that intensive fishing mortality in juvenile areas with a high nursery contribution may cause local effects in cod but potentially could affect stock-level recruitment in haddock.

The evidence for east to west movement of haddock from settlement to spawning could reflect a return migration of advected offspring, since model simulations suggest that a significant component of the haddock eggs spawned off the Scottish west coast are transported into the North Sea (Heath \& Gallego 1997). The possibility of a return natal migration is not without precedent, since stage-related differences in distribution and unexpected appearances of mature haddock on spawning grounds in the northwest Atlantic have been interpreted as a return migration of dispersed progeny to natal grounds (Frank 1992, Brickman 2003). Alternatively, dispersal of pre-settled stages and extensive movements of juveniles may reflect opportunistic and non-philopatric recruitment of juveniles to adult aggregations. Clearly, further work is needed on the larval origins of settled juveniles to explore whether the exchange relates to natal fidelity or non-philopatric recruitment. Nevertheless, regardless of mechanism, the present study does demonstrate high connectivity between nursery areas both within and between the 2 managed stock units.

Currently, the North Sea and west of Scotland haddock stocks are assessed and managed as separate units, with the former being around 5 to 10 times the biomass of the latter (ICES 2008a,b). The east-west movement of young fish between stock regions, indicated by the present study, could lead to an apparent increase in mortality in the North Sea and decrease in the west of Scotland. Given the relative abundance in the 2 regions, any negative effect of recruits moving to the west coast from the North Sea would be marginal compared to the positive effect seen in west coast numbers. Clearly, the age at which post-settled juveniles move to the west coast is important, since the fishery is targeted at fish 2 yr old and older (ICES 2008b).

Area closures designed to reduce mortality of undersized individuals can be beneficial to stock management and, if small, could cause little effort re-allocation and reduction in yield (Apostolaki et al. 2002, Le Quesne et al. 2007). The present study does suggest that relatively small regions may act as important nurseries and, although fishing mortality on newly settled haddock, similar to those examined in the present study, is negligible, it rises dramatically at ages 1 and 2 (ICES 2008a). Therefore, if juveniles remained in these areas from 0-group up until maturation then the protection from high discarding by effort restriction in such areas might be beneficial. Indeed, past regulations to restrict small meshed fisheries for Norway pout Trisopterus esmarkii in the SEC region were associated with an overall decrease in North Sea haddock mortality. However, this decrease could have also been related to changes in the distribution of fishing effort linked to Norway pout distribution and modifications of gear (Anon. 1987, ICES 2008a). In some recent years the mass of discarded undersized haddock in the North Sea has exceeded the landings of fish for human consumption (ICES 2008a), highlighting the need for measures to protect juveniles.

The present study adds to the debate over the utility of permanent area closures for protecting young fish. Nursery value of areas may change in relation to yearclass variability (Yamashita et al. 2000, Kraus \& Secor 2005). Given the inter-annual changes in juvenile distribution of North Sea haddock, temporary closures of high-density areas might be expected to have a greater impact on undersized mortality than permanent closures if contribution always tends to reflect density. Similarly, Frank et al. (2000) reported that following an area closure on the Emerald/Western Bank, the proportion of haddock juveniles within the closed 
area steadily declined, resulting in the majority of year-classes remaining unprotected. High recruitment variation has also been reported for Rockall Bank haddock following the closure of an area to protect juveniles in 2001 (Newton et al. 2008). Clearly, further evidence is needed to support the link between demersal juvenile density and nursery contribution before management measures could be proposed. Further studies investigating contribution over several year-classes are therefore needed. Future studies also need to determine the age at which juvenile haddock disperse from their nursery areas since this will affect the length of time during which closures could reduce undersize mortality. Temporal sampling of otolith chemistry using laser ablation ICP-MS would provide a possible approach to develop such an understanding of the timing of these movements.

Acknowledgements. We are indebted to A. R. Kean from the Inorganic Analytical Services, Research and Productivity Council (RPC) in New Brunswick, Canada for isotope analyses. We are grateful to R. Millar for the program HISEA. This research was funded by the Scottish Government (MF 0464). F. Neat, J. Augley, R. Fryer and 3 anonymous reviewers provided valuable comments on an earlier draft of the manuscript. We gratefully acknowledge the help in sample collection of the skippers, crew and scientific staff onboard the FRVs 'Clupea' and 'Scotia' and survey data from the ICES DATRAS database.

\section{LITERATURE CITED}

Anon (1987) The consequences of increased North Sea herring, haddock and whiting abundances for the fishery for Norway pout in the North Sea. EU Commission Report, Contract No. 1946, 12.06.1987. Marine Resources Assessment Group, London, and Danish Institute for Fisheries and Marine Research, Charlottenlund

Apostolaki P, Milner-Gulland EJ, McAllister MK, Kirkwood GP (2002) Modelling the effects of establishing a marine reserve for mobile fish species. Can J Fish Aquat Sci 59: 405-415

Bailey RM (1975) Observations on diel behaviour patterns of North Sea gadoids in the pelagic phase. J Mar Biol Assoc UK 55:133-142

Bath GE, Thorrold SR, Jones CM, Campana SE, McLaren JW, Lam JWH (2000) Strontium and barium uptake in aragonitic otoliths of marine fish. Geochim Cosmochim Acta 64: 1705-1714

Beck MW, Heck KL Jr, Able KW, Childers DL and others (2001) The identification, conservation, and management of estuarine and marine nurseries for fish and invertebrates. Bioscience 51:633-641

Bigelow H, Schroeder W (1953) Fishes of the Gulf of Maine. Fish Bull Fish Wildl Serv 74:88-99

Brickman D (2003) Controls on the distribution of Browns Bank juvenile haddock. Mar Ecol Prog Ser 263:235-246

Bromley PJ, Kell LT (1999) Vertical migration and spatial distribution of pelagic 0-group gadoids (cod, haddock, whiting and Norway pout) prior to and during settlement in the North Sea. Acta Adriat 40:7-17
Brown JA (2006) Using the chemical composition of otoliths to evaluate the nursery role of estuaries for English sole Pleuronectes vetulus populations. Mar Ecol Prog Ser 306: 269-281

Campana SE (1999) Chemistry and composition of fish otoliths: pathways, mechanisms and applications. Mar Ecol Prog Ser 188:263-297

Campana SE, Chouinard GA, Hanson JM, Frechet A, Brattey $\mathrm{J}$ (2000) Otolith elemental fingerprints as biological tracers of fish stocks. Fish Res 46:343-357

> Charlier BLA, Ginibre C, Morgan D, Nowell GM, Pearson DG, Davidson JP, Ottley CJ (2006) Methods for the microsampling and high-precision analysis of strontium and rubidium isotopes at single crystal scale for petrological and geochronological applications. Chem Geol 232: $114-133$

Dahlgren CP, Kellison GT, Adams AJ, Gillanders BM and others (2006) Marine nurseries and effective juvenile habitats: concepts and applications. Mar Ecol Prog Ser 312: 291-295

Demain D (2009) Settlement ecology of juvenile cod Gadus morhua, haddock Melanogrammus aeglefinus and whiting Merlangius merlangus. PhD dissertation, University of Aberdeen

> Dorval E, Jones CM, Hannigan R, van Montfrans J (2007) Relating otolith chemistry to surface water chemistry in a coastal plain estuary. Can J Fish Aquat Sci 64:411-424

Dybern BI, Danielssen DS, Hernroth L, Svendsen E (1994) The Skagerrak experiment. SKAGEX report 1988-1994. TemaNord 635:1-34

Elsdon TS, Wells BK, Campana SE, Gillanders BM and others (2008) Otolith chemistry to describe movements and lifehistory parameters of fishes: hypotheses, assumptions, limitations and inferences. Oceanogr Mar Biol Annu Rev 46:297-330

Fernandes PG, Rivoirard J (1999) A geostatistical analysis of the spatial distribution and abundance of cod, haddock and whiting in North Scotland. In: Gomez-Hernández J, Soares AO, Froidevaux R (eds) geoENV II-geostatistics for environmental applications. Quantitive Geology and Geostatistics, Vol 10. Kluwer Academic Publishers, Dordrecht, p 201-212

> Frank KT (1992) Demographic consequences of age-specific dispersal in marine fish populations. Can J Fish Aquat Sci 49:2222-2231

> Frank KT, Shackell NL, Simon JE (2000) An evaluation of the Emerald/Western Bank juvenile haddock closed area. ICES J Mar Sci 57:1023-1034

Gibb FM, Gibb IM, Wright PJ (2007) Isolation of Atlantic cod (Gadus morhua) nursery areas. Mar Biol 151:1185-1194

Gillanders BM (2002) Connectivity between juvenile and adult fish populations: Do adults remain near their recruitment estuaries? Mar Ecol Prog Ser 240:215-223

Gillanders BM, Kingsford MJ (1996) Elements in otoliths may elucidate the contribution of estuarine recruitment to sustaining coastal reef populations of a temperate reef fish. Mar Ecol Prog Ser 141:13-20

Gillanders BM, Sanchez-Jerez P, Bayle-Sempere J, RamosEspla A (2001) Trace elements in otoliths of the twobanded bream from a coastal region in the south-west Mediterranean: Are there differences among locations? J Fish Biol 59:350-363

> Halpern BS, Gaines SD, Warner RR (2004) Confounding effects of the export of production and the displacement of fishing effort from marine reserves. Ecol Appl 14: 1248-1256

Heath M, Gallego A (1997) From the biology of the individual 
to the dynamics of the population: bridging the gap in fish early life studies. J Fish Biol 51(Suppl A):1-29

Heath M, Rankine P, Cargill L (1994) Distribution of cod and haddock eggs in the North Sea in 1992 in relation to oceanographic features and compared with distributions in 1952-1957. ICES Mar Sci Symp 198:244-253

- Hedger R, McKenzie E, Heath M, Wright PJ, Scott B, Gallego A, Andrews J (2004) Analysis of the spatial distributions of mature cod (Gadus morhua) and haddock (Melanogrammus aeglefinus) abundance in the North Sea (1980-1999) using generalised additive models. Fish Res 70:17-25

Horwood JW, Nichols JH, Milligan S (1998) Evaluation of closed areas for fish stock conservation. J Appl Ecol 35: 893-903

Huberty CJ (1994) Applied discriminant analysis. Wiley Interscience, New York

Hunt JJ (1992) Morphological characteristics of otoliths for selected fish in the Northwest Atlantic. J Northwest Atl Fish Sci 13:63-75

ICES (2008a) Haddock in Subarea IV (North Sea) and Division IIIaN (Skagerrak). ICES Advice 2008, Book 6. ICES, Copenhagen

ICES (2008b) Haddock in Division VIa (West of Scotland). ICES Advice 2008, Book 5. ICES, Copenhagen

Jamieson A, Birley AJ (1989) The distribution of transferrin alleles in haddock stocks. ICES J Mar Sci 45:248-262

Jaworski A, Solmundsson J, Ragnarsson SA (2006) The effect of area closures on the demersal fish community off the east coast of Iceland. ICES J Mar Sci 63:897-911

Jones R (1959) A method of analysis of some tagged haddock returns. J Cons Int Explor Mer XXV:58-72

Jónsdóttir IG, Marteinsdóttir G, Campana SE (2007) Contribution of different spawning components to the mixed stock fishery for cod in Icelandic waters. ICES J Mar Sci 64:1749-1759

Kraus RT, Secor DH (2005) Application of the nursery-role hypothesis to an estuarine fish. Mar Ecol Prog Ser 291: 301-305

Le Quesne WJF, Hawkins SJ, Shepherd JG (2007) A comparison of no-take zones and traditional fishery management tools for managing site-attached species with a mixed larval pool. Fish Fish 8:181-195

Lipcius RN, Stockhausen WT, Eggleston DB, Marshall LS Jr, Hickey B (1997) Hydrodynamic decoupling of recruitment, habitat quality and adult abundance in the Caribbean spiny lobster: source-sink dynamics? Mar Freshw Res 48:807-815

Lough RG, Valentine PC, Potter DC, Auditore PJ, Bolz GR, Neilson JD, Perry RI (1989) Ecology and distribution of juvenile cod and haddock in relation to sediment type and bottom currents on eastern Georges Bank. Mar Ecol Prog Ser 56:1-12

McBride RS, Able KW (1998) Ecology and fate of butterflyfish,

Editorial responsibility: Hans Heinrich Janssen, Oldendorf/Luhe, Germany
Chaetodon spp., in the temperate, western North Atlantic. Bull Mar Sci 63:401-416

Millar RB (1990a) Comparison of methods for estimating mixed stock fishery composition. Can J Fish Aquat Sci 47: 2235-2241

Millar RB (1990b) A versatile computer program for mixed stock fishery composition estimation. Can Tech Rep Fish Aquat Sci 1753:1-29

Miller MB, Clough AM, Batson JN, Vachet RW (2006) Transition metal binding to cod otolith proteins. J Exp Mar Biol Ecol 329:135-143

> Neat FC, Wright PJ, Zuur AF, Gibb IM and others (2006) Residency and depth movements of a coastal group of Atlantic cod (Gadus morhua, L.). Mar Biol 148:643-654

> Newton AW, Peach KJ, Coull KA, Gault M, Needle CL (2008) Rockall and the Scottish haddock fishery. Fish Res 94: 133-140

Reid D, Beare DJ, Mahe J-C, Connolly P, Davis CG, Newton AW (2000) Quantifying variability in gear performance on IBTS surveys: swept area and volume with depth. ICES CM 2000/K:28. ICES, Copenhagen

Saville A (1959) The planktonic stages of the haddock in Scottish waters. Mar Res 93:1-23

Temming A, Floeter J, Ehrich S (2007) Predation hot spots: large scale impact of local aggregations. Ecosystems 10: 865-876

> Thorrold SR, Latkoczy C, Swart PK, Jones CM (2001) Natal homing in a marine fish metapopulation. Science 291: 297-299

Tobin D, Wright PJ, Gibb FM, Gibb IM (in press) The importance of life stage to population connectivity in whiting (Merlangius merlangus) from the northern European shelf. Mar Biol

Walther BD, Thorrold SR (2006) Water, not food, contributes the majority of strontium and barium deposited in the otoliths of a marine fish. Mar Ecol Prog Ser 311:125-130

White JW, Ruttenberg BI (2007) Discriminant function analysis in marine ecology: some oversights and their solutions. Mar Ecol Prog Ser 329:301-305

Wright PJ, Gibb FM (2005) Selection for birth date in North Sea haddock and its relation to maternal age. J Anim Ecol 74:303-312

> Wright PJ, Neat FC, Gibb FM, Gibb IM, Thordarson H (2006a) Evidence for metapopulation structuring in cod from the west of Scotland and North Sea. J Fish Biol 69(Suppl C): 181-199

Wright PJ, Galley E, Gibb IM, Neat FC (2006b) Fidelity of adult cod to spawning grounds in Scottish waters. Fish Res 77:148-158

Yamashita Y, Otake T, Yamada H (2000) Relative contributions from exposed inshore and estuarine nursery grounds to the recruitment of stone flounder, Platichthys bicoloratus, estimated using otolith $\mathrm{Sr}$ :Ca ratios. Fish Oceanogr 9:316-327

Submitted: May 14, 2009; Accepted: October 22, 2009 Proofs received from author(s): February 4, 2010 